\title{
In vitro long-term treatment with MAPK inhibitors induces melanoma cells with resistance plasticity to inhibitors while retaining sensitivity to $\mathrm{CD8} \mathrm{T}$ cells
}

\author{
FLORENCIA PAULA MADORSKY ROWDO ${ }^{1}$, ANTONELA BARÓN ${ }^{1}$, \\ ERIKA MARÍA VON EUW ${ }^{2}$ and JOSÉ MORDOH ${ }^{1,3}$
}

${ }^{1}$ Leloir Institute, IIBBA-CONICET, Buenos Aires, Argentina; ${ }^{2}$ Department of Medicine, Division of Hematology-Oncology, Jonsson Comprehensive Cancer Center, University of California, Los Angeles, CA, USA; ${ }^{3}$ FUCA Center of

Oncology Research and Alexander Fleming Institute, Buenos Aires, Argentina

Received July 26, 2016; Accepted September 10, 2016

DOI: 10.3892/or.2017.5363

\begin{abstract}
The development of BRAF V600 and MEK inhibitors constitutes a breakthrough in the treatment of patients with BRAF-mutated metastatic melanoma. However, although there is an increase in overall survival, these patients generally confront recurrence, and several resistance mechanisms have already been described. In the present study we describe a different resistance mechanism. After several weeks of long-term in vitro treatment of two different V600E BRAF-mutated melanoma cell lines with MARK inhibitors, PLX4032 and/or GDC-0973, the majority of the cells died whereas some remained viable and quiescent (SUR). Markedly, discontinuing treatment of SUR cells with MAPK inhibitors allowed the population to regrow and these cells retained drug sensitivity equal to that of the parental cells. SUR cells had increased expression levels of CD271 and ABCB5 and presented senescence-associated characteristics. Notably, SUR cells were efficiently lysed by cytotoxic T lymphocytes recognizing MART-1 and gp100 melanoma differentiation antigens. We propose quiescent plasticity as a mechanism of resistance to BRAF and MEK inhibitors while retaining sensitivity to immune effectors.
\end{abstract}

Correspondence to: Dr José Mordoh, Leloir Institute, IIBBA-CONICET, Av. Patricias Argentinas 435, 1405 Buenos Aires, Argentina

E-mail: jmordoh@leloir.org.ar

Abbreviations: CM, cutaneous melanoma; CSCs, cancer stem cells; CTLs, cytotoxic T lymphocytes; MAPKi, MAPK inhibitors; MDA, melanoma differentiation antigen; SA- $\beta-$ Gal, senescence-associated $\beta$-galactosidase

Key words: melanoma, BRAF, phenotypic plasticity, PLX4032, GDC-0973

\section{Introduction}

Human cutaneous melanoma (CM) has been, until recently, resistant to conventional chemotherapy. However, the finding that approximately $50 \%$ of human CM harbor the driver mutations V600E or V600K in the BRAF oncogene, a component of the MAPK pathway (1), led to the development of MAPK inhibitors (MAPKi), such as vemurafenib (PLX4032) and dabrafenib directed either to the BRAFmutated protein (2-4), and cobimetinib (GDC-0973) and trametinib targeting downstream kinase MEK $(2,5,6)$. A phase III clinical study of vemurafenib, alone or combined with cobimetinib, demonstrated the superiority of the drug combination, with progression-free survival increasing from 6.9 months for PLX4032 alone to 9.9 months for the combination (7). The utility of dual BRAF V600E and MEK inhibition was confirmed in a phase III trial in which dabrafenib alone was compared to dabrafenib plus trametinib, with an increased progression-free survival from 8.8 to 9.3 months (8). In both studies, although the overall response rates were higher than $60 \%$, the number of complete responses was only $10 \%$. Several resistance mechanisms, most of them involving a reactivation of the MAPK pathway, have been described (9-14), but no effective solution to drug resistance has been found. Intriguingly, Long et al analyzed biopsies from 15 patients obtained before, early after treatment and on progression after treatment with vemurafenib or dabrafenib. They observed that inhibition of proliferative markers was universal yet unrelated to clinical response, but that cell death markers were more prominent in responders (15). Therefore, the link between inhibition of the MAPK pathway, triggered apoptosis, necrosis and ensuing clinical responses remains to be established. A possible explanation for clinical relapses could be the presence in tumors of 'persister' cells, a subpopulation of cancer cells that survives targeted therapy and that could be responsible for therapy failure and tumor progression $(16,17)$.

Another successful approach to CM therapy has been the introduction of immune checkpoint inhibitors (18-20). Although different lines of evidence suggest that the 
combination of MAPK-targeted therapies with immunotherapy may offer additional benefit to eliminate residual disease, treatment with BRAF-mutated inhibitors apparently increases melanoma differentiation antigen (MDA) expression $(21,22)$ and $\mathrm{T}$ cell tumor infiltration $(23)$. At present it is not known whether MAPK inhibition and immunotherapy may be successfully combined in the clinic. Due to the difficulty in obtaining biopsies from treated patients, we undertook such analysis using BRAF V600E mutated cell lines. In this study we employed MAPKi to investigate in vitro whether surviving populations exist after long-term MAPKi treatment and, if that were the case, their sensitivity to immune effectors. We report that after exposure to MAPKi for several weeks, alone or in combination, a small number of cells remained alive (SUR) and displayed a complex phenotype with overlapping characteristics of cancer stem cells (CSCs) and senescent cells. When released from drug inhibition, SUR cells proliferated and regained their parental drug sensitivity. Most importantly, we demonstrated that SUR cells were sensitive to $\mathrm{CD}^{+}$effectors, thereby providing a useful system for analyzing combination therapy.

\section{Materials and methods}

Cell lines. The MEL-XY3 cell line has already been described (24). The MEL-XY13 cell line was obtained from a lymph node amelanotic metastasis of an 82-year-old male patient. Both cell lines are HLA-A*0201-positive and have the BRAF V600E mutation, and c-kit (exons 11 and 17) and Nras (exons 2 and 3) sequencing revealed no additional mutations. Both cell lines were grown in melanoma medium (MM) (25) plus $10 \%$ fetal bovine serum (FBS) (Natocor, Carlos Paz, Córdoba, Argentina) at $37^{\circ} \mathrm{C}$ in air: $\mathrm{CO}_{2}(95: 5 \%)$ humid incubator.

MEL-XY3 $3_{\text {SUR }}$ and MEL-XY13 $3_{\text {SUR }}$ were generated by exposing cancer cells to $10 \mu \mathrm{M}$ PLX4032, $1 \mu \mathrm{M}$ GDC-0973 or combined treatment for 5 weeks. Media were changed twice a week. PLX4032 and GDC-0973 were provided by Genentech (South San Francisco, CA, USA).

DNA synthesis. DNA synthesis was assessed by measuring ${ }^{3}[\mathrm{H}]$-labeled thymidine incorporation. Ten thousand cells/well were seeded in 96-well plates in $200 \mu \mathrm{l}$ of MM. When indicated, cells were incubated overnight and PLX4032 and/or GDC-0973 were subsequently added for different periods. After performing a 2 -h pulse at $37^{\circ} \mathrm{C}$ with $1 \mu \mathrm{Ci} / \mathrm{ml}$ ${ }^{3}[\mathrm{H}]$-labeled thymidine (Perkin-Elmer, Boston, MA, USA), the cells were harvested with a NuncCell Harvester 8 (Nalge Nunc International Corp., Rochester, NY, USA) and the incorporated radioactivity was determined with a liquid scintillation counter (Wallac 1214 RackBeta; Pharmacia, Turku, Finland).

MTT cell viability assay. Cells were seeded in 96-well flat-bottomed plates in triplicate. Twenty-four hours later, serial dilutions of PLX4032 and/or GDC-0973 were added. After incubation for $72 \mathrm{~h}, 100 \mu \mathrm{l}$ of $1 \mathrm{mg} / \mathrm{ml} \mathrm{3-(4,5-dimeth-}$ ylthiazol-2-yl)-2,5-diphenyltetrazolium bromide (MTT; Sigma-Aldrich, St. Louis, MO, USA) diluted in MM were added to each well and incubation was carried out for $90 \mathrm{~min}$. The supernatant was discarded and the crystal products were
Table I. List of primers.

\begin{tabular}{|c|c|}
\hline Genes & Sequences \\
\hline CD271 & $\begin{array}{l}\text { F: CTGGACAGCGTGACGTTCTCC } \\
\text { R: CTGCCACCGTGCTGGCTATGA }\end{array}$ \\
\hline CD133 & $\begin{array}{l}\text { F: GGACCCATTGGCATTCTC } \\
\text { R: CAGGACACAGCATAGAATAATC }\end{array}$ \\
\hline ABCB5 & $\begin{array}{l}\text { F: CCAAATCGGGGGCTGCGCATCTGTT } \\
\text { R: AGCCGCTGCTCCCCACAAATGCTA }\end{array}$ \\
\hline$\beta$-actin & $\begin{array}{l}\text { F: GCCATCTCTTGCTCGAAGTCCAG } \\
\text { R: ATGTTTGAGACCTTCAACACCCC }\end{array}$ \\
\hline Sox 10 & $\begin{array}{l}\text { F: GACCAGTACCCGCACCTG } \\
\text { R: CGCTTGTCACTTTCGTTCAG }\end{array}$ \\
\hline Sox 2 & $\begin{array}{l}\text { F: CAGTCTGCCGAGAATCCATG } \\
\text { R: TTTTTTTTTTCAGTGTCCATATTTC }\end{array}$ \\
\hline NanoG & $\begin{array}{l}\text { F: CAGCTGTGTGTACTCAATGATAGA } \\
\text { R: ACACCATTGCTATTCTTCGGCCAG }\end{array}$ \\
\hline Oct4 & $\begin{array}{l}\text { F: ACATCAAAGCTCTGCAGAAAGAACT } \\
\text { R: CTGAATACCTTCCCAAATAGAACCC }\end{array}$ \\
\hline NGF & $\begin{array}{l}\text { F: TCATCATCCCATCCCATCTT } \\
\text { R: CTTGACAAAGGTGTGAGTCG }\end{array}$ \\
\hline BDNF & $\begin{array}{l}\text { F: AGCCTCCTCTTCTCTTTCTGCTGGA } \\
\text { R: CTTTGTCTATGCCCCTGCAGCCTT }\end{array}$ \\
\hline NT-3 & $\begin{array}{l}\text { F: TTTCTCGCTTATCTCCGTGGCATCC } \\
\text { R: GGCAGGGTGCTCTGGTAATTTTCCT }\end{array}$ \\
\hline NT-4 & $\begin{array}{l}\text { F: ATGCTCCCTCTCCCCTCAT } \\
\text { R: GCATGGGTCTCAGGCCCG }\end{array}$ \\
\hline MART-1 & $\begin{array}{l}\text { F: GAGAAAAACTGTGAACCTGTGGT } \\
\text { R: GACTGTTCTGCAGAGAGTTTCTCAT }\end{array}$ \\
\hline gp100 & $\begin{array}{l}\text { F: GCTGATCGTGGGCATCTTG } \\
\text { R: AGTGACTGCTGCTATGTGG }\end{array}$ \\
\hline Tyr & $\begin{array}{l}\text { F: TCTGCCAACGATCCTATCT } \\
\text { R: AATGGGTGCATTGGCTTCT }\end{array}$ \\
\hline Trp-2 & $\begin{array}{l}\text { F: CGACTCTGATTAGTCGGAACTCA } \\
\text { R: GGTGGTTGTAGTCATCCAAGC }\end{array}$ \\
\hline MITF & $\begin{array}{l}\text { F: CGAGCTCATGGACTTTCCCTTA } \\
\text { R: CTTGATGATCCGATTCACCAAA }\end{array}$ \\
\hline
\end{tabular}

resuspended with isopropyl alcohol and incubated for $1 \mathrm{~h}$ at $30^{\circ} \mathrm{C}$. Colorimetric evaluation was performed with a spectrophotometer at $570 \mathrm{~nm}$. The inhibition of proliferation induced by the drugs was shown as the percentage of the growth of the untreated control cells. $\mathrm{IC}_{50}$ was determined using GraphPad Prism 5.0 software.

Quantitative real-time reverse transcriptase PCR ( $R T-q P C R)$. Total RNA was purified using TRIzol reagent (Ambion, Invitrogen, Carlsbad, CA, USA) according to the manufacturer's instructions. Quantification was performed with a NanoDrop 2000 (Thermo Fisher Scientific, Inc., Wilmington, DE, USA). One microgram of RNA was reverse-transcribed using SuperScript ${ }^{\mathrm{TM}}$ II Reverse Transcriptase (Invitrogen, 
Carlsbad, CA, USA). The product was used in subsequent RT-qPCR using KAPA SYBR FAST Universal Master Mix (Applied Biosystems, Carlsbad, CA, USA) with the primers listed in Table I. Relative expression levels were determined by the $\Delta \Delta \mathrm{Cq}$ method (26), using $\beta$-actin gene expression to normalize all samples. A melting curve analysis and gel electrophoresis assessment were used to confirm the specificity of PCR reactions.

Western blot analysis. Cells were detached, centrifuged, washed with cold phosphate-buffered saline (PBS) and resuspended in RIPA lysis buffer and protease inhibitor cocktail (Sigma-Aldrich). Phosphatase inhibitor cocktail 2 (Sigma-Aldrich) and $\mathrm{NaF} 10 \mathrm{mM}$ were added for phospho-protein determinations. Cell extracts were run on a $10 \%$ SDS-PAGE gel and transferred to a nitrocellulose membrane (Immobilon, 0.45- $\mu \mathrm{m}$ pore size, HATF 304 FO; Millipore, Bedford, MA, USA). After blocking in 3\% BSA with PBS, the blots were incubated with mouse anti-human CD271 mAb (clone C40-1457; BD Pharmingen, San Jose, CA, USA), rabbit anti-ERK1 polyclonal Ab (Santa Cruz Biotechnology, Inc., Santa Cruz, CA, USA), rabbit anti-p-ERK polyclonal Ab (Cell Signaling Technology, Inc., Beverly, MA, USA) or mouse anti- $\beta$-actin (clone AC-74; Sigma-Aldrich). After being washed, blots were further incubated with $1 / 2,500$ alkaline phosphatase-AffiniPure $\mathrm{F}\left(\mathrm{ab} \mathrm{b}^{\prime}\right)_{2}$ fragment goat anti-mouse IgG $(\mathrm{H}+\mathrm{L})$ (Jackson ImmunoResearch Laboratories, Inc., West Grove, PA, USA) and developed with nitro blue tetrazolium/5-bromo-4-chloro-3-indolyl phosphate (NBT-BCIP) (Promega, Madison, WI, USA). Alternatively, blots were incubated with peroxidase anti-rabbit antibody (Vector Laboratories, Burlingame, CA, USA), developed with SuperSignal West Dura Extended Duration substrate (Thermo Fisher Scientific, Rockford, IL, USA), and chemoluminescence was measured in an ImageQuant LAS 4000 instrument (GE Healthcare, Uppsala, Sweden).

Flow cytometry. Cells were incubated with human-specific CD271 (clone C40-1457; BD Pharmingen), MART-1 (2A9) (27), gp100 (clone Hmb45; Dako, Glostrup, Denmark) and HLA-A2-PE (clone BB7.2; BD Pharmingen) antibodies for $1 \mathrm{~h}$ at $4^{\circ} \mathrm{C}$. Before the use of MART-1 and gp100 antibodies a permeabilization step with $0.1 \%$ saponin was performed. Washed cells were resuspended in PBS and stored on ice or labeled with RPE conjugated anti-mouse polyclonal Ab (1:50; Dako). Ag expression was assessed using a FACSCalibur flow cytometer (BD Biosciences, San Diego, CA, USA). Analysis was performed with the FlowJo 7.6 software. Isotype-matched mouse antibodies were used as controls.

For the carboxyfluorescein succinimidyl ester (CFSE) assay, cells were detached, washed with PBS and labeled with $10 \mu \mathrm{M}$ CFSE according to the manufacturer's indications (Invitrogen), and then plated for $96 \mathrm{~h}$ in the presence or absence of PLX4032. Cells were then detached and analyzed with a FACSCalibur flow cytometer.

For cell cycle analysis, cells were detached and fixed with $70 \%$ ethanol $\mathrm{ON}$ at $4^{\circ} \mathrm{C}$. Cells were stained with propidium iodide solution $(50 \mu \mathrm{g} / \mathrm{ml}$ with $100 \mu \mathrm{g} / \mathrm{ml}$ RNase A in PBS) for $30 \mathrm{~min}$ at $37^{\circ} \mathrm{C}$. Cells were analyzed on a FACSCalibur flow cytometer using the FlowJo 7.6 software for data analysis.
MACS. Magnetic-activated cell sorting (MACS) to separate the CD271 ${ }^{+}$and CD271' subpopulations was performed according to the manufacturer's instructions using anti-human-specific CD271 (clone C40-1457; BD Pharmingen), anti-mouse IgG microbeads and MS columns (Miltenyi Biotec, Bergisch Gladbach, Germany). Sorting verification was performed by flow cytometry.

SA- $\beta$-Gal staining. Cells were either left untreated or were treated with $10 \mu \mathrm{M}$ PLX4032 for $72 \mathrm{~h}$ or 5 weeks. Senescence-associated $\beta$-galactosidase (SA- $\beta$-Gal) staining was performed according to the chromogenic assay described by Debacq-Chainiaux et al (28).

Reverse-phase protein array (RPPA) analysis. Cell lysates were 2-fold serial diluted for five dilutions (from undiluted to 1:16 dilutions) and arrayed on nitrocellulose-coated slides. Samples were probed with antibodies by a tyramide-based signal amplification approach and visualized by DAB colorimetric reaction. Slides were scanned on a flatbed scanner to produce 16-bit tiff images. Spots from tiff images were identified and the density was quantified by an Array-Pro Analyzer. Relative protein levels for each sample were determined by interpolation of each dilution curve from the standard curve (supercurve) of the slide (antibody). All data points were normalized for protein loading and transformed into a linear value and normalized linear values were transformed to $\log _{2}$ values.

In vivo tumorigenicity assay. $\mathrm{NOD} / \mathrm{LtSz}$-scid IL2R $\gamma^{\text {null }}$ mice (NSG) were subcutaneously injected with 500 MEL-XY3 parental or MEL-XY3 $3_{\text {SUR-PLX }}$ cells in a suspension of Matrigel

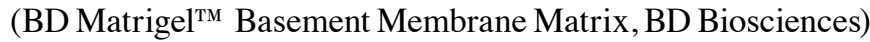
with PBS in a 1:1 ratio. Tumor growth was monitored three times a week for the entire period of the experiment. Tumor size was assessed using a caliper to calculate tumor volume (V) by applying the formula: $\mathrm{V}=[$ length $(\mathrm{mm})] \mathrm{x}$ [width $(\mathrm{mm})]^{2} / 2$. All animal procedures were approved by the Institutional Animal Care Board of the Leloir Institute (Buenos Aires, Argentina).

In vitro lysis of melanoma cells by cytotoxic T lymphocyte (CTL) clones. To determine lysis, effector $\mathrm{CD}^{+}$lymphocytes (E) specific for the HLA-A*0201 restricted MART-1 (M27:AAGIGILTV) or gp100 (G154:KTWGQYWQV) antigens (29) and target MEL-XY3 (control, MEL-XY3 $3_{\text {SUR-PLX }}$ or MEL-XY3 $3_{\text {SUR-GDC }}$ ) cells (T) were incubated overnight at different E:T ratios (1:1, 5:1 and 10:1) in AIM V medium (Invitrogen, Grand Island, NY, USA). Cells were recovered and plated in quadruplicate for a clonogenic assay. For this, the cells were resuspended in $\mathrm{MM}+10 \% \mathrm{FBS}$ with $1.5 \%$ methylcellulose (Sigma-Aldrich), plated at 1,000 cells/well on MW24 plates over a $0.5 \%$ agar MM $+10 \%$ FBS underlayer and incubated for 14 days. Colonies $\geq 30$ cells were counted using an inverted Olympus microscope.

ELISA IFN- $\gamma$ secretion. IFN- $\gamma$ secretion into the supernatant by cytotoxic $\mathrm{T}$ cells was determined with a BD OptEIA human IFN- $\gamma$ ELISA kit (BD Biosciences), following the manufacturer's recommendations. A calibration curve was constructed for each experiment and the sample concentration was calculated by regression analysis. Controls for this 
A

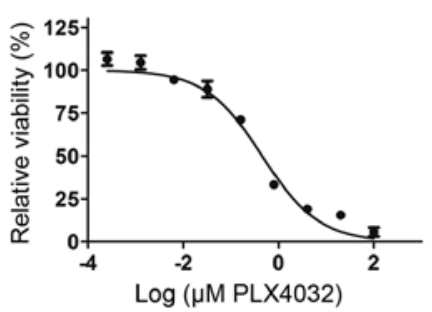

C

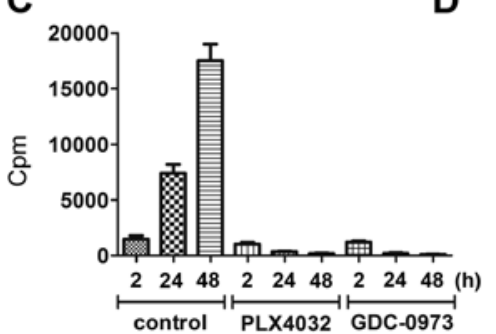

Figure 1. Effect of PLX4032 and GDC-0973 on MEL-XY3 cells. MEL-XY3 cells were treated with different concentrations of (A) PLX4032 (0-100 $\mu \mathrm{M})$ or (B) GDC-0973 $(0-10 \mu \mathrm{M})$ for $72 \mathrm{~h}$ and viability was determined using MTT assay. Data are shown relative to DMSO-treated controls. (C) MEL-XY3 DNA synthesis was assessed at different time-points $(0,24$ and $48 \mathrm{~h})$ in control, $10 \mu \mathrm{M}$ PLX4032 or $1 \mu \mathrm{M}$ GDC-0973-treated cells. (D) MEL-XY3 cells were treated with PLX4032 $10 \mu \mathrm{M}$ or GDC-0973 $1 \mu \mathrm{M}$ for $30 \mathrm{~min}$ and protein lysates were analyzed by western blot analysis for p-ERK and ERK.

experiment included CM cell lines HLA-A*0201-negative that do not express MART-1 or gp100 and the IIB-BRG breast cancer cell line HLA-A*0201-positive that does not express MART-1 or gp100 (negative controls) and CTLs alone.

\section{Results}

Long-term treatment with MAPKi results in a surviving population of nonproliferating cells. Since clinical resistance to MAPKi almost always emerges after months of treatment, we sought to determine whether some cells remained viable after long-term treatment of BRAF-mutated cell lines with MAPKi and, if so, to characterize them. Accordingly, we first investigated the effect of PLX4032 and GDC-0973 on the MEL-XY3 CM cell line, heterozygous for the BRAF V600E mutation. MEL-XY3 cells were sensitive to PLX4032 ( $\mathrm{IC}_{50} 0.45 \mu \mathrm{M}$ ) (Fig. 1A) and to GDC-0973 ( $\mathrm{IC}_{50}$ $0.1 \mathrm{nM}$ ) (Fig. 1B). Inhibition of the MAPK pathway was also confirmed by inhibition of DNA synthesis (Fig. 1C) and of ERK phosphorylation (Fig. 1D). Though some DNA synthesis occurred within 0-2 h of inhibitor treatment, after 24 and $48 \mathrm{~h}$ it was totally abolished. ERK phosphorylation was inhibited 30 min after starting PLX4032 and GDC-0973 treatment. The effect of short-term treatment of MEL-XY3 with both PLX4032 and GDC-0973 was cytostatic, with cells starting to detach after a few days. We next exposed MEL-XY3 cells to $10 \mu \mathrm{M}$ PLX4032 for 5 weeks; some cells remained attached and viable (Fig. 2A, left) and were detectable even after five months of treatment. We referred to this subpopulation of surviving cells as MEL-XY3 $3_{\text {SUR-PLX }}$. We analyzed the fate of MEL-XY $3_{\text {SUR-PLX }}$ cells when the inhibitor was removed. After an initial period of several days, in which some cells presented
A
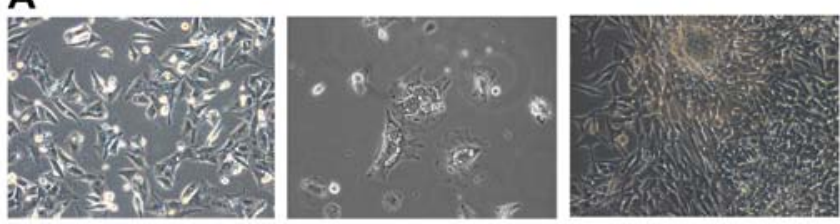

B

C
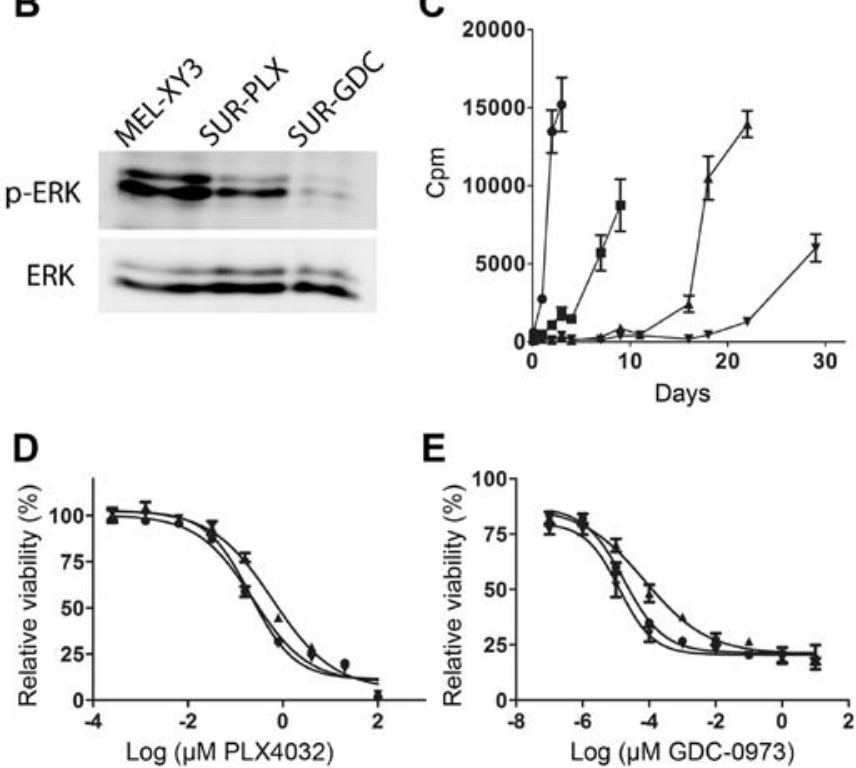

E

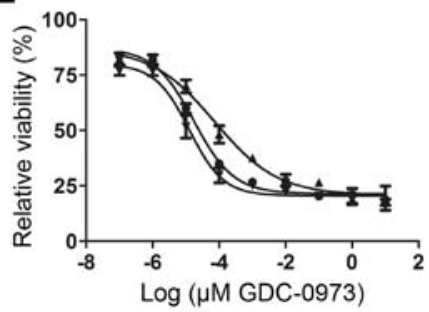

Figure 2. MEL-XY3 $3_{\text {SUR }}$ cells obtained after PLX4032 and GDC-0973 long-term treatment. (A) Phase contrast images of MEL-XY3 $3_{\text {SUR-PLX }}$ (left) and MEL-XY3 $3_{\text {SUR-PLX }}$ cells $24 \mathrm{~h}$ (middle) and 7 days (right) after PLX4032 removal from culture medium. Original magnification, x100. (B) Western blot analysis for p-ERK and ERK. (C) DNA synthesis was assessed at different time-points in MEL-XY3 (circles); MEL-XY3 $3_{\text {SUR-PLX }}$ (squares) MEL-XY $3_{\text {SUR-GDC }}$ (triangles) and MEL-XY3 $3_{\text {SUR-PLX-GDC }}$ (inverted triangles) cells after drug removal. (D and E) MEL-XY3 (circles), MEL-XY3 $3_{\text {SUR-PLX }}$ after drug removal (triangles) and MEL-XY3 $3_{\text {SUR-GDC }}$ cells after drug removal (inverted triangles) were treated with different concentrations of (D) PLX4032 $(0-100 \mu \mathrm{M})$ or (E) GDC-0973 $(0-10 \mu \mathrm{M})$ for $72 \mathrm{~h}$ and viability was determined using MTT assay. Data are shown relative to DMSO-treated controls.

abundant cytoplasmic vesicles and some detached from the plates (Fig. 2A, middle), MEL-XY3 $3_{\text {SUR-PLX }}$ cells re-established vigorous growth (Fig. 2A, right), and generated cells with a similar phenotype to the parental cell line.

In order to determine whether such a quiescent phenotype could also be generated by other MAPKi, MEL-XY3 cells were maintained in the presence of $1 \mu \mathrm{M}$ GDC-0973 for 5 weeks; a small, viable subpopulation with analogous characteristics to MEL-XY3 $3_{\text {SUR-PLX }}$ cells was also observed, and was named MEL-XY3 $3_{\text {SUR-GDC }}$. After combined treatment with $10 \mu \mathrm{M}$ PLX4032 and $1 \mu \mathrm{M}$ GDC-0973 (MEL-XY3 $3_{\text {SUR-PLX-GDC }}$ ), surviving cells with a similar phenotype were observed. The status of the MAPK pathway in MEL-XY3 $3_{\text {SUR-PLX }}$ and MEL-XY3 $3_{\text {SUR-GDC }}$ cells while they were in the presence of the inhibitors was investigated. MEL-XY $3_{\text {SUR-PLX }}$ cells presented lower levels of p-ERK than parental cells, although somewhat higher than MEL-XY3 $3_{\text {SUR-GDC }}$ cells (Fig. 2B).

When we studied DNA synthesis at different time-points after drug removal, we observed that MEL-XY3 $3_{\text {SUR-PLX }}$ cells started proliferation before MEL-XY3 $3_{\text {SUR-GDC }}$, 
A

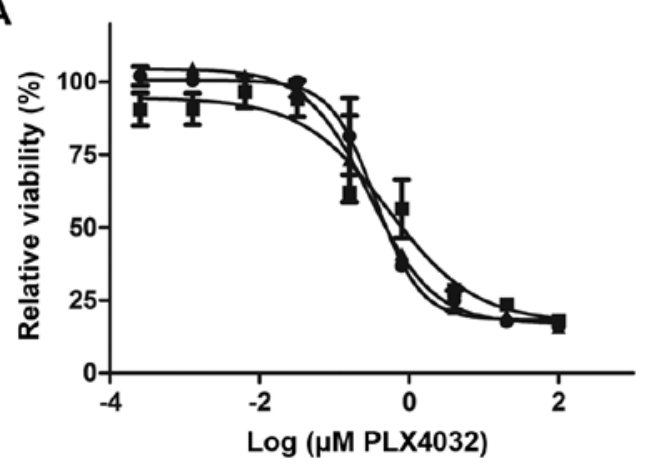

C

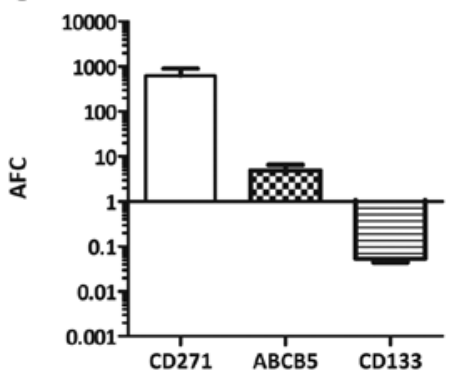

D

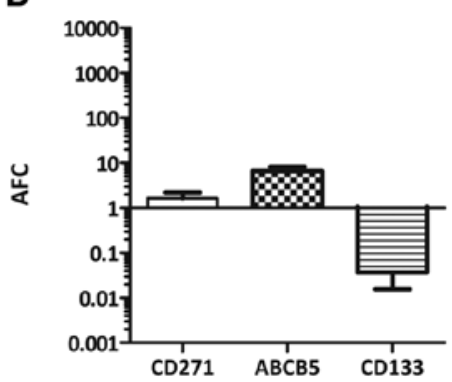

B

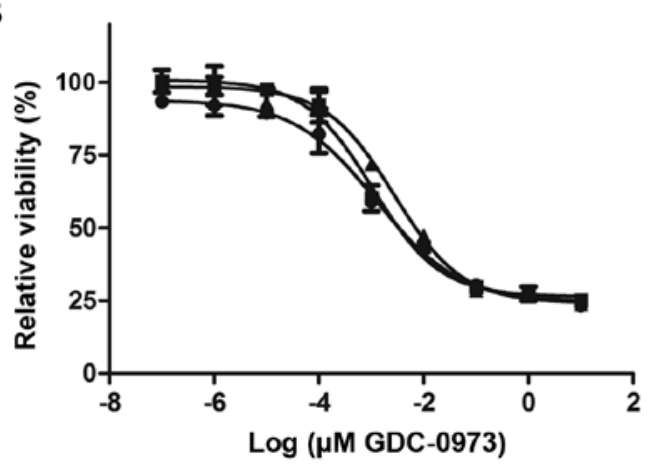

E

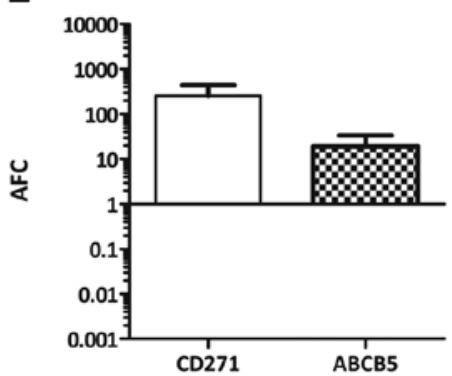

Figure 3. MEL-XY13 ${ }_{\text {SUR }}$ cells maintain sensitivity to MAPKi and express putative cancer stem cell markers. MEL-XY13 (circles), MEL-XY13 ${ }_{\text {SUR-PLX }}$ after drug removal (squares) and MEL-XY13 $3_{\text {SUR-GDC }}$ after drug removal (triangles) were treated with different concentrations of (A) PLX4032 (0-100 $\left.\mu \mathrm{M}\right)$ or (B) GDC-0973 $(0-10 \mu \mathrm{M})$ for $72 \mathrm{~h}$ and viability was determined using MTT assay. Data are shown relative to DMSO-treated controls. mRNA expression levels

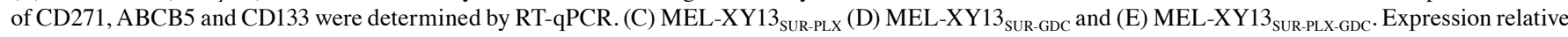

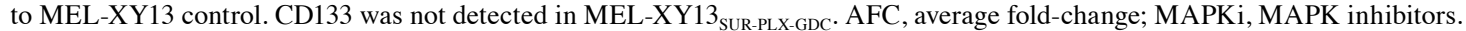

while MEL-XY3 $3_{\text {SUR-PLX-GDC }}$ cells were the last to resume growth (Fig. 2C). Notably, after a 5-week treatment with PLX4032 or GDC-0973, and allowing treated cells to regrow in the absence of the inhibitors, their sensitivity to PLX4032 or GDC-0973 remained unaltered with respect to the parental cells (Fig. 2D and E).

In order to evaluate whether the SUR phenotype also arose in other melanoma cell lines, we studied MAPKi treatment in the MEL-XY13 cell line. This cell line is heterozygous for the BRAF V600E mutation and sensitive to PLX4032 $(0.36 \mu \mathrm{M})$ and GDC-0973 (1.25 nM). When MEL-XY13 cells were treated for 5 weeks with PLX4032 or GDC-0973, MEL-XY13 $3_{\text {SUR-PLX }}$ and MEL-XY13 ${ }_{\text {SUR-GDC }}$, respectively, were obtained. Furthermore, when the drugs were removed, MEL-XY13 ${ }_{\text {SUR }}$ cells restarted growth and their sensitivity to PLX4032 and GDC-0973 was equal to the parental cell line (Fig. 3A and B).

Phenotypic characterization of $M E L-X Y 3_{\text {SUR }}$ cells. Since MEL-XY $3_{\text {SUR }}$ cells were non-proliferating and different reports associate drug resistance with the CSC phenotype, we sought to determine whether they displayed some CSC characteristics. After treatment with $10 \mu \mathrm{M}$ PLX4032 for 5 weeks, we analyzed the expression levels of putative CSC markers, such as CD271, ABCB5 and CD133 (prominin-1) (30-32). As compared to parental MEL-XY3, the mRNA levels for CD271 and ABCB5 in MEL-XY3 $3_{\text {SUR-PLX }}$ cells increased 1,000- and 30-fold, respectively, whereas CD133 levels decreased (Fig. 4A). MEL-XY3 $3_{\text {SUR-GDC }}$ cells obtained after $1 \mu \mathrm{M}$ of GDC-0973 treatment (Fig. 4B) and
MEL-XY3 $3_{\text {SUR-PLX-GDC }}$ obtained after the combined treatment with both inhibitors (Fig. 4C) also had increased CD271 and ABCB5 mRNA levels, although the increase in CD271 was smaller. Similar results were obtained with MEL-XY13 ${ }_{\text {SUR }}$, with the exception that in MEL-XY13 ${ }_{\text {SUR-GDC }}$ cells, CD271 mRNA levels did not change (Fig. 3C-E). Increased CD271 expression in MEL-XY3 $3_{\text {SUR-PLX }}$ cells was confirmed at the protein level by flow cytometry (Fig. 4D) and by western blot analysis (Fig. 4E). In the flow cytometric analysis of MEL-XY3 $3_{\text {SUR-PLX }}$ cells, two peaks were observed, demonstrating the presence of two cell subpopulations.

We also analyzed whether changes in CD271 ligand expression also took place in the MEL-XY $3_{\text {SUR-PLX }}$ cells; all the mRNA levels of neurotrophins that bind CD271 (NGF, BDNF, NT-3, NT-4) increased 10- to -300-fold (Fig. 4F). Expression levels of the stem cell associated transcription factors Sox10, Sox 2, Oct4 and Nanog were also determined, and a modest 2 - to 4-fold increase was observed in MEL-XY3 $3_{\text {SUR-PLX }}$ cells (Fig. 4G). We analyzed the expression time course of ABCB5, CD271 and CD133 in MEL-XY3 cells exposed to $10 \mu \mathrm{M}$ PLX4032 at different time-points. ABCB5 expression rapidly increased and remained at high levels during the 5-week treatment. Instead, CD271 expression did not increase until the third week of treatment and CD133 started decreasing after 2 weeks of treatment (Fig. 4H). In order to determine whether CD271 and ABCB5 were uniformly expressed in the MEL-XY3 $3_{\text {SUR-PLX }}$ cell population, CD271 ${ }^{+}$ and $\mathrm{CD}_{271^{-}}$cells were separated by magnetic sorting. CD271- predominated over CD $271^{+}$cells but both expressed ABCB5 (Fig. 4I), suggesting that the expression of both 
A

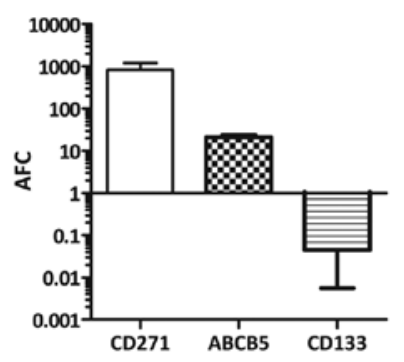

D

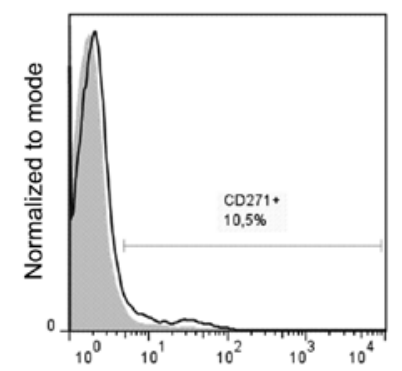

$\mathbf{F}$

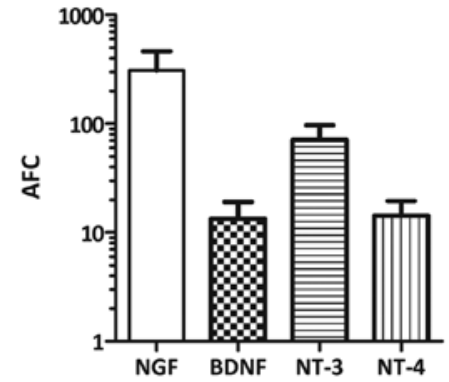

H

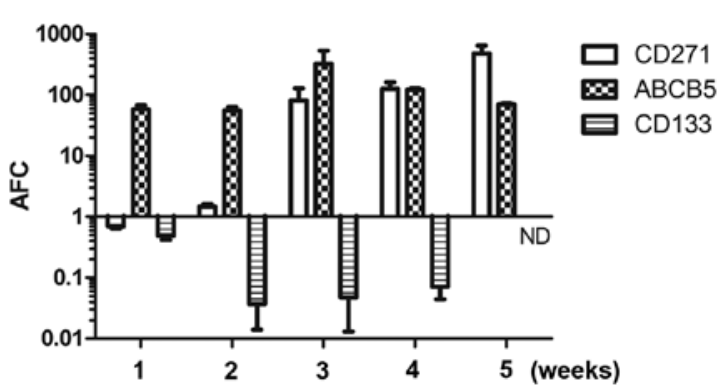

B
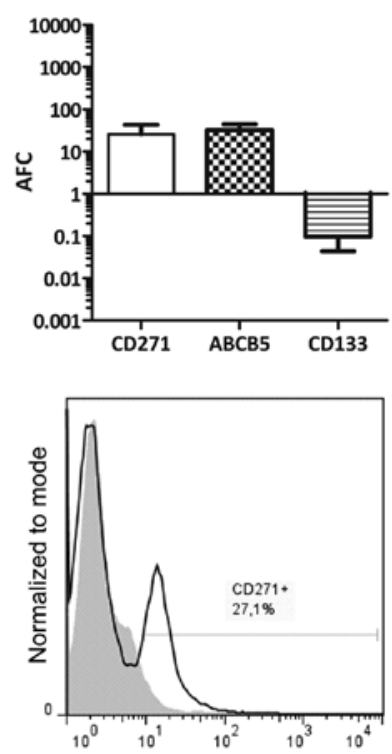

C

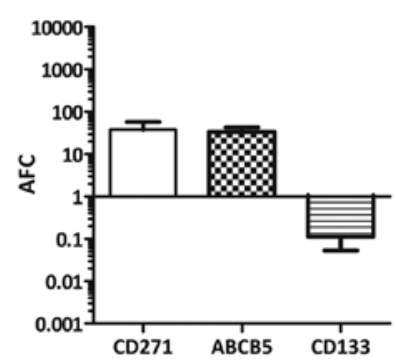

$E$

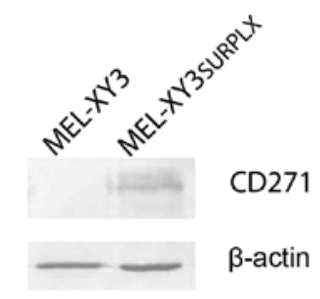

G

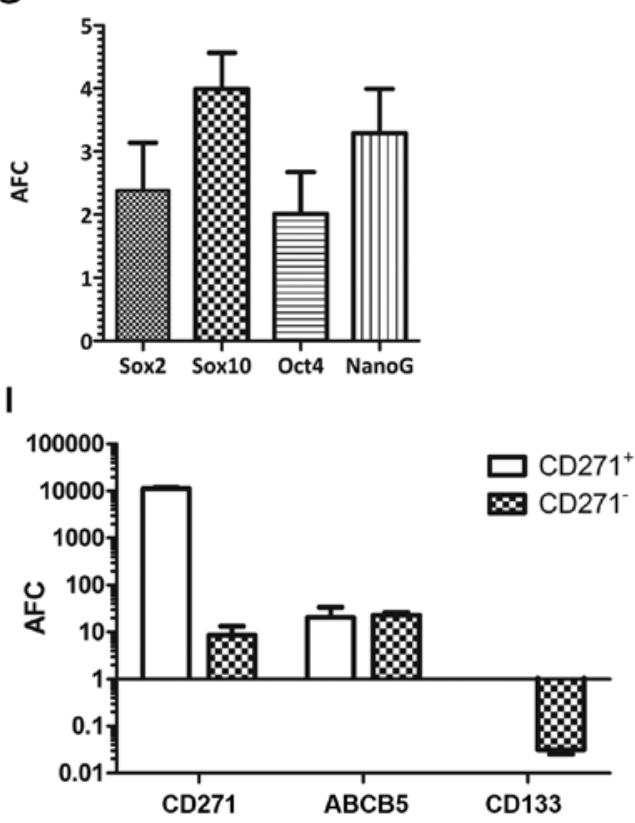

Figure 4. MEL-XY3 $3_{\text {SUR }}$ cells express putative CSC markers. mRNA expression levels of CD271, ABCB5 and CD133 in (A) MEL-XY3 $3_{\text {SUR-PLX }}$ (B) MEL-XY3 $3_{\text {SUR-GDC }}$ and (C) MEL-XY3 $3_{\text {SUR-PLX-GDC }}$ cells. (D) MEL-XY3 parental (left) and MEL-XY3 $3_{\text {SUR-PLX }}$ (right) CD271 expression was determined by flow cytometry. Representative histograms are shown. Gray-filled histogram, isotype-matched control; black line, CD271. (E) Western blot analysis for CD271 expression. $\beta$-actin was used as loading control. mRNA expression levels of (F) neurotrophins and $(\mathrm{G})$ stem cell transcription factors in MEL-XY3 $3_{\text {SuR-PLX }}$. (H) mRNA expression levels of CD271, ABCB5 and CD133 in MEL-XY3 cells treated with $10 \mu \mathrm{M}$ PLX4032 for the indicated times. (I) mRNA expression levels of CD271, ABCB5 and CD133 in sorted MEL-XY3 $3_{\text {SUR-PLX }}$ CD271 ${ }^{+}$and CD271 cells. In every case, mRNA levels were determined by RT-qPCR, relative to parental MEL-XY3. AFC, average fold-change; CSC, cancer stem cell.

markers was not related. CD133 mRNA was not detected in CD271 ${ }^{+}$MEL-XY3 $3_{\text {SUR-PLX }}$.

$M E L-X Y 3_{\text {SUR }}$ cells present senescence-associated features. It has been previously shown that PLX4032 and another mutant BRAF inhibitor, LGX818 (encorafenib), induce senescent characteristics in melanoma cells $(33,34)$. It has also been shown that the expression of mutated BRAF in normal melanocytes determines oncogene-induced senescence (35). Therefore, we decided to investigate senescent characteristics in our SUR population. The cell cycle of MEL-XY $3_{\text {SUR-PLX }}$ and MEL-XY3 $3_{\text {SUR-GDC }}$ was analyzed by flow cytometry, and a decrease in the $\mathrm{S}$ phase and an increase in the proportion of cells in the G0/G1 phase were observed, consistent with the observations of Fig. 2 (Fig. 5A).

We then analyzed senescence-associated- $\beta$-galactosidase (SA- $\beta$-gal) activity in MEL-XY3 $3_{\text {SUR-PLX }}$. Although MEL-XY3 cells treated with $10 \mu \mathrm{M}$ PLX4032 for $72 \mathrm{~h}$ did not stain positive for SA- $\beta$-gal, most MEL-XY3 $3_{\text {SUR-PLX }}$ cells did (Fig. $5 B$ ), thereby suggesting senescence. To further investigate other 
A

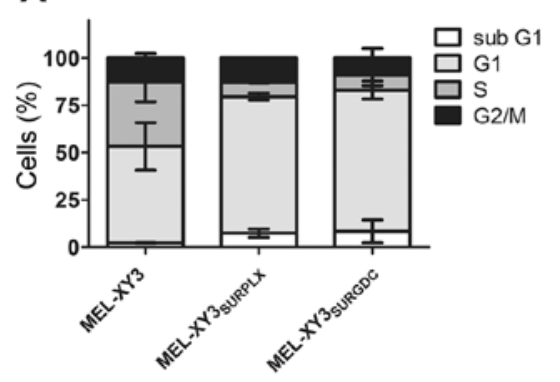

B
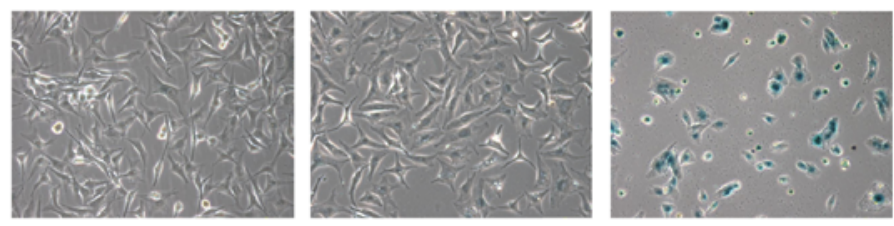

C

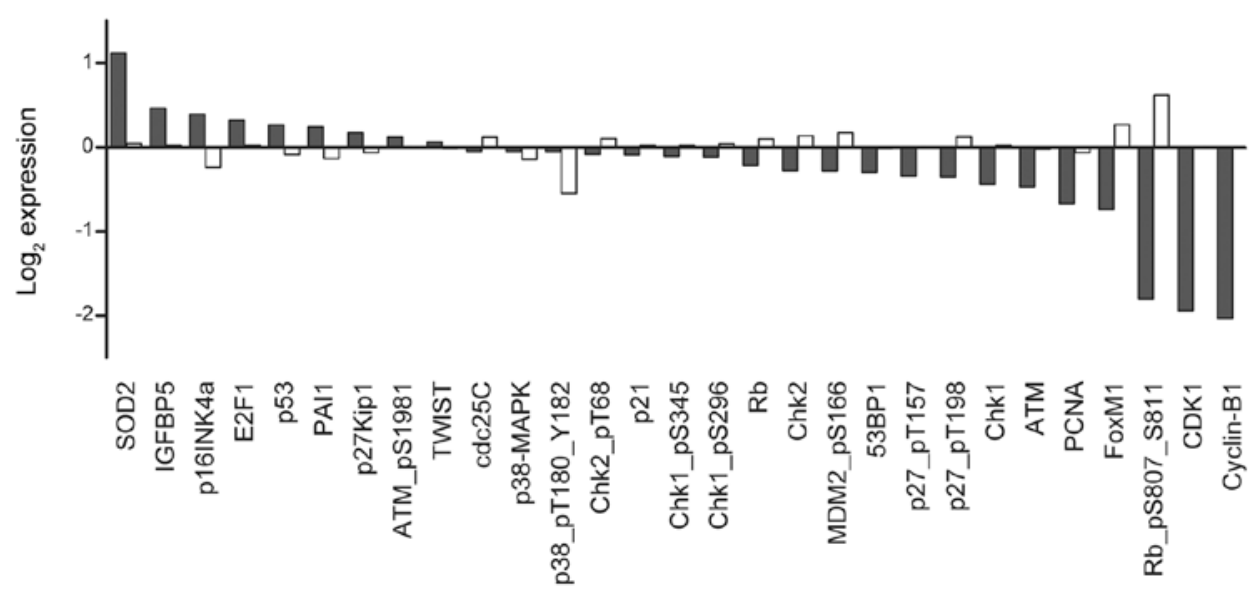

Figure 5. MEL-XY3 $3_{\text {SUR }}$ cells present senescence-associated features. (A) Cell cycle profile of MEL-XY3, MEL-XY $3_{\text {SUR-PLX }}$ and MEL-XY3 $3_{\text {SUR-GDC }}$ (B) SA- $\beta$-Gal staining of MEL-XY3 (left), MEL-XY3 treated with PLX4032 for $72 \mathrm{~h}$ (middle) and MEL-XY3 $3_{\text {SUR-PLX }}$ (right). Original magnification, x100. (C) Expression of senescence-associated genes by RPPA analyses in parental MEL-XY3 (white) and MEL-XY3 $3_{\text {SUR-PLX }}$ cells (gray). SA- $\beta$-Gal, senescence-associated $\beta$-galactosidase; RPPA, reverse-phase protein array.

A
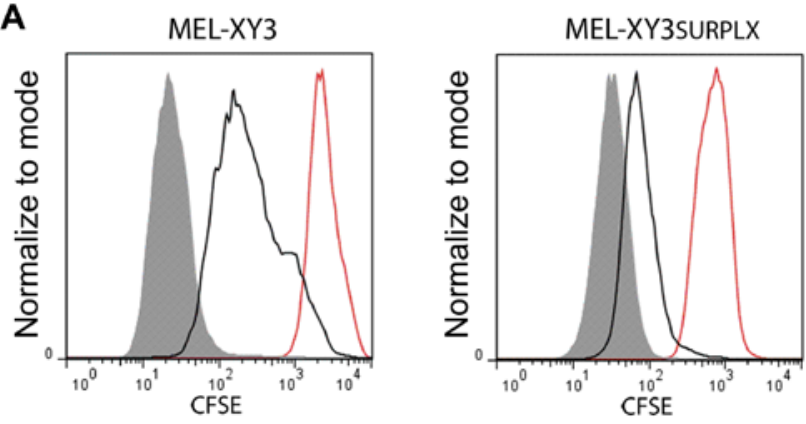

B

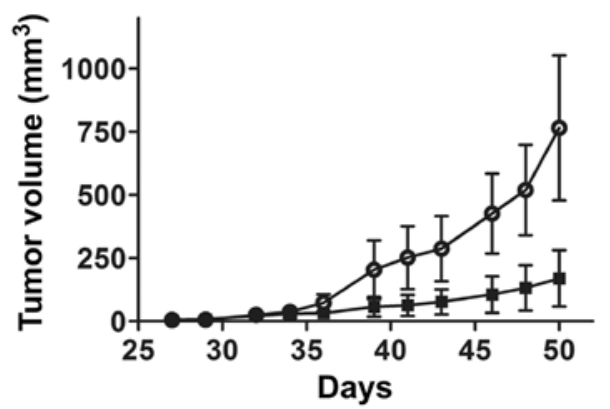

Figure 6. Cell division of MEL-XY3 $3_{\text {SUR }}$ cells after drug removal and in vivo tumor growth. (A) Representative histograms of flow cytometric analysis of CFSE-labeled MEL-XY3 (left) and MEL-XY3 $3_{\text {SUR-PLX }}$ (right) cells. The histogram plot on day 0 is displayed in gray. The black and gray-filled lines represent the histogram plots of the CFSE fluorescence, following $96 \mathrm{~h}$ in the presence and absence of $10 \mu \mathrm{M}$ PLX4032, respectively. (B) Tumor volume after subcutaneous injection into NOD/LtSz-scid IL2R $\gamma^{\text {null }}$ mice (NSG) of $500 \mathrm{MEL}-\mathrm{XY} 3$ parental (squares) or MEL-XY3 ${ }_{\text {SUR-PLX }}$ cells (circles). $\mathrm{n}=8$ per group. CFSE, carboxyfluorescein succinimidyl ester. senescence-related proteins, we performed a RPPA (Fig. 5C). In relation to the parental cell line, senescence-related proteins superoxide dismutase 2 (SOD2), insulin-like growth factor binding protein-5 (IGFBP5) and $\mathrm{p} 16^{\mathrm{INK} 4}$ were increased. On the other hand, E2F1, p53, plasminogen activator inhibitor-1 (PAI1) and $\mathrm{p} 27^{\mathrm{kip} 1}$ displayed only small changes. In MEL-XY3 $3_{\text {SUR-PLX }}$ cells, there was also a general decrease in cell cycle-related proteins, with striking decreases in $\mathrm{p}-\mathrm{Rb}$, CDK1 and cyclin B1.

Variable phenotype of $M E L-X Y 3_{\text {SUR }}$. We next investigated whether MEL-XY $3_{\text {SUR-PLX }}$ and MEL-XY $3_{\text {SUR-GDC }}$ quiescent cells coexisted in the cell line with proliferating cells before MAPKi treatment. If that were the case, it could be assumed that after drug removal and growth resumption, at least a portion of SUR cells would remain quiescent, thereby confirming that they are a 'reservoir' for proliferating cells. On the other hand, if quiescence is a transitory, variable state induced by chemotherapy, every surviving cell would leave behind its quiescence and start regrowth when the drugs were removed. We stained MEL-XY $3_{\text {SUR-PLX }}$ cells with CFSE, and they remained in culture for $96 \mathrm{~h}$ in the absence or presence of the inhibitor; retention of the label was then analyzed. During those $96 \mathrm{~h}$, MEL-XY $3_{\text {SUR-PLX }}$ cells underwent two rounds of cell division without leaving behind a resting subpopulation. When a similar experiment was performed with the parental cell line, three rounds of cell division were achieved (Fig. 6A). This experiment suggests that tumor cell plasticity and phenotypic 

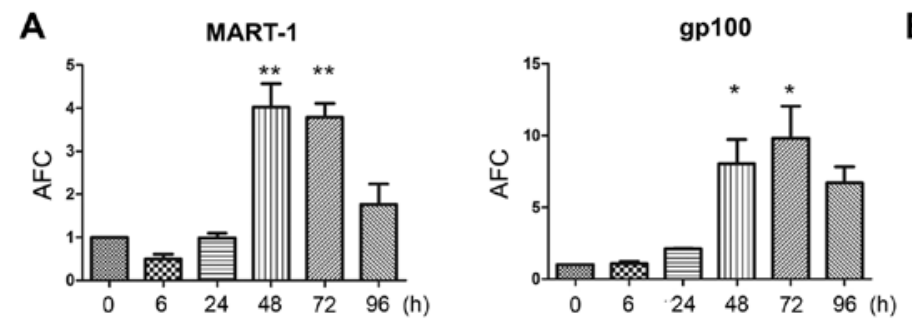

B
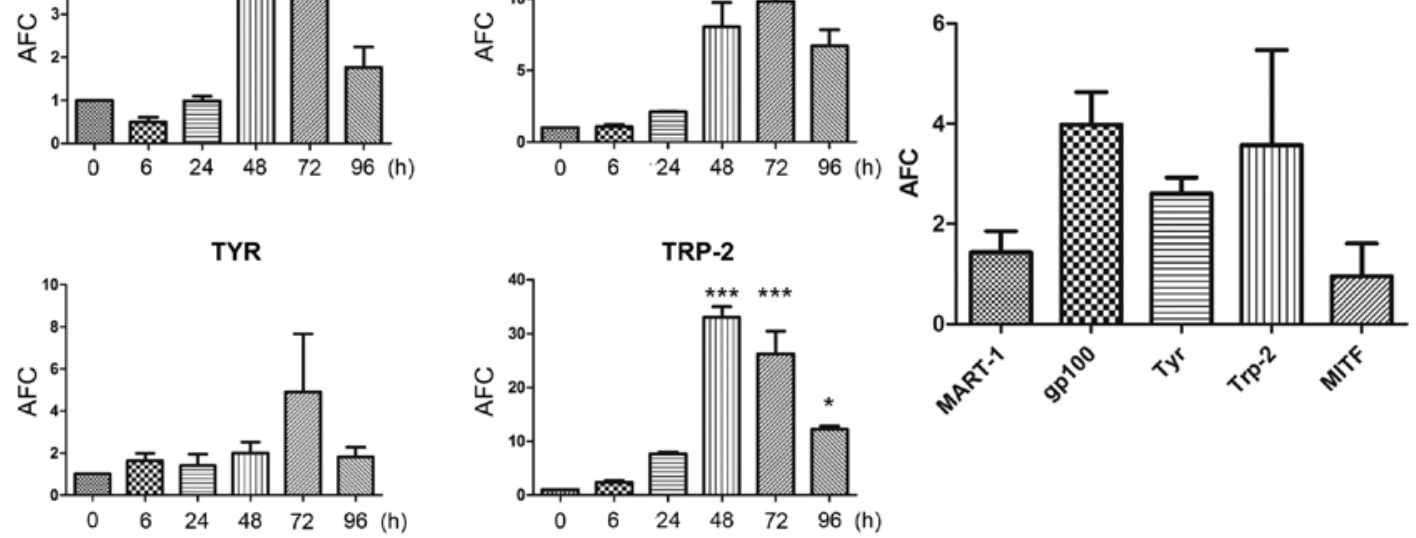

C
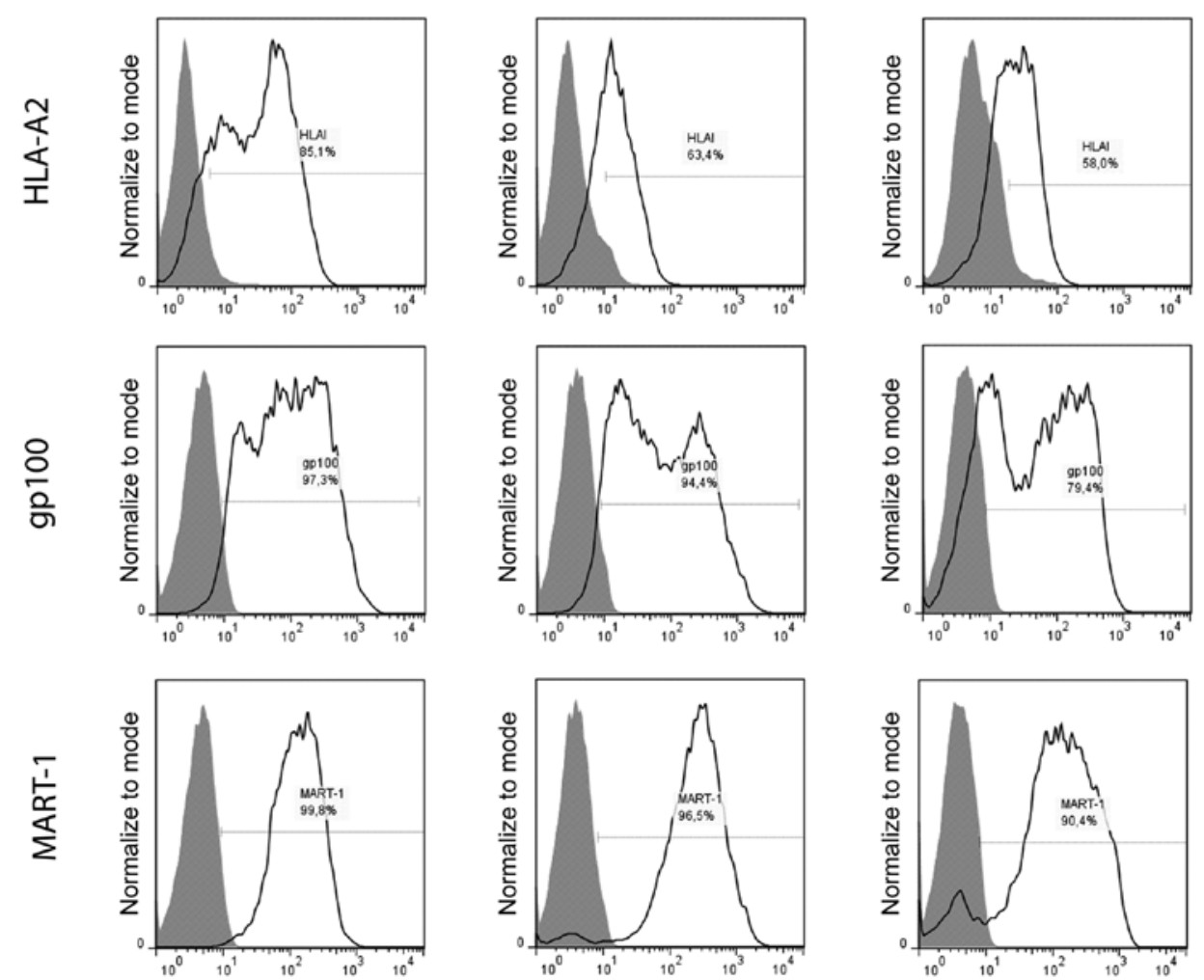

Figure 7. MDA expression levels in MEL-XY3-treated cells. (A) mRNA expression levels of MART-1, gp100, Tyr and Trp-2 in MEL-XY3 cells treated with $10 \mu \mathrm{M}$ PLX4032 for different time-points. (B) mRNA expression levels of MART-1, gp100, Tyr, Trp-2 and MITF in MEL-XY3 $3_{\text {suR-PLX }}$ cells. mRNA levels were determined by RT-qPCR. AFC with respect to parental cells; (C) HLA-A2, MART-1 and gp100 protein expression levels were determined by flow cytometry. Representative histograms for MEL-XY3 (left), MEL-XY3 $3_{\text {SUR-PLX }}$ (middle) and MEL-XY3 $3_{\text {SUR-GDC }}$ (right) are shown. Gray-filled histogram, isotype-matched control; black line, HLA-A2 (upper panel), gp100 (middle panel) and MART-1 (lower panel). MDA, melanoma differentiation antigen; AFC, average fold-change. ${ }^{*} \mathrm{p}<0.05,{ }^{* *} \mathrm{p}<0.01,{ }^{* * * *} \mathrm{p}<0.001$.

switching would account for the previously described acquisition of quiescence. When the same experiment was performed with the MEL-XY3 $3_{\text {SUR-GDC }}$ cells, no cell division was observed after $96 \mathrm{~h}$, which is consistent with the lagging DNA synthesis after drug removal (Fig. 2C).

Tumorigenicity of MEL-XY3 $3_{\text {SUR-PLX }}$ cells. To determine whether MEL-XY $3_{\text {SUR-PLX }}$ cells retained their tumorigenic potential, we injected 500 cells into NSG mice and compared their growth rate with parental MEL-XY3 cells. Even though both cell types developed tumors, MEL-XY3 $3_{\text {SUR-PLX }}$ grew faster than parental cells, although the difference was not statistically significant (Fig. 6B).

Sensitivity of SUR cells to MDA-directed CTL clones. It has been reported that MDA expression increases after PLX4032 treatment, both in vitro and in patients $(21,22)$. We confirmed increased mRNA levels of MDAs MART-1, gp100, TYR and Trp-2 when MEL-XY3 cells were treated with $10 \mu \mathrm{M}$ PLX4032 for $72 \mathrm{~h}$ (Fig. 7A). We found that 
A

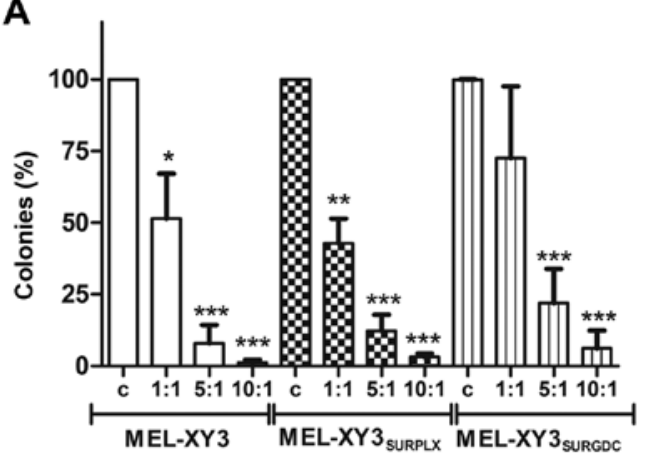

C

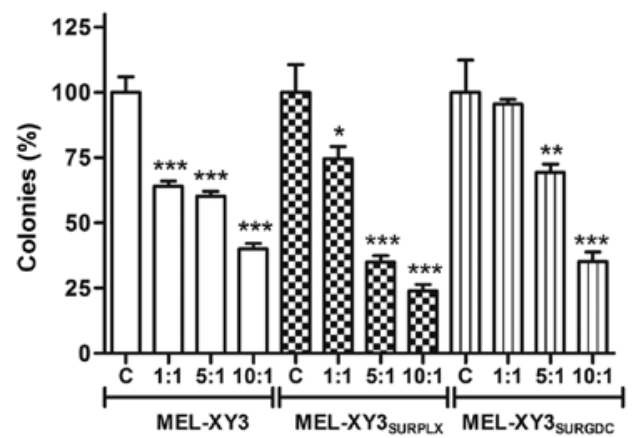

E

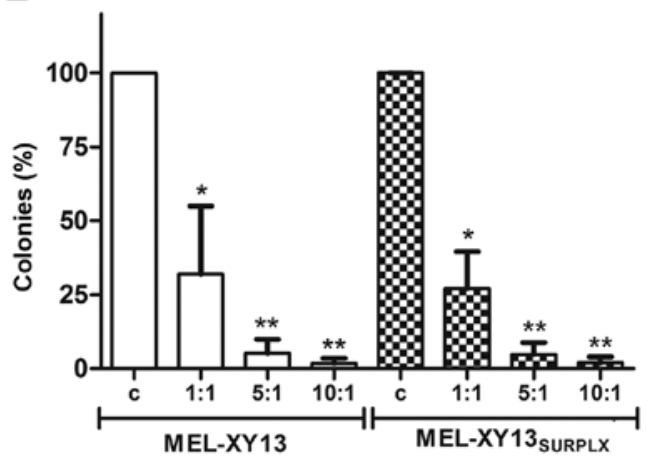

B

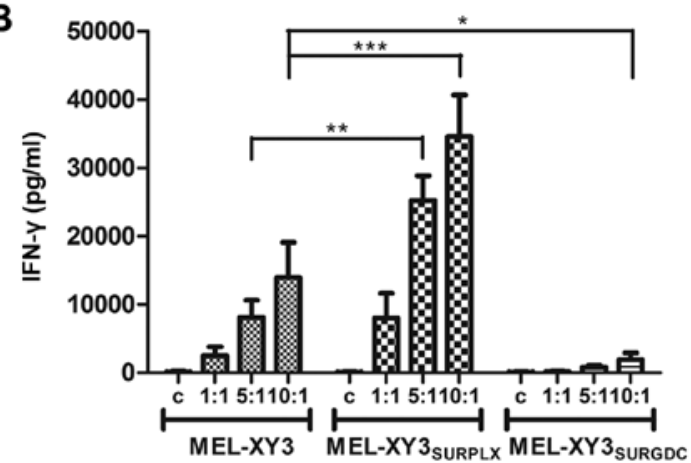

D

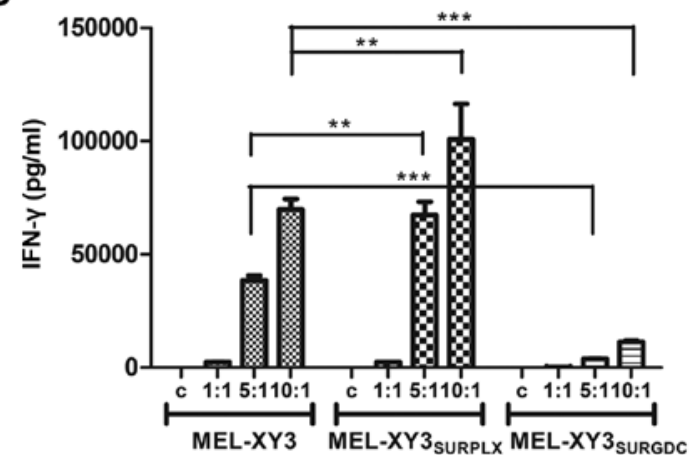

$\mathbf{F}$

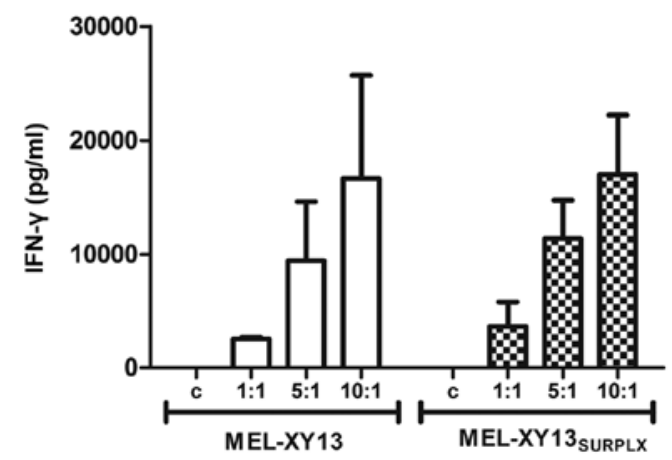

Figure 8. Lysis of melanoma cells by MART-1 and gp100-specific CTL. Target cells were incubated with effector (A, B, E and F) gp100 CTL (C and D) MART-1 CTL. Effector:target cells ratio 1:1, 5:1, 10:1; c, control without effector cells. (A, C and E) Cell lysis was determined by inhibition of colony formation (\%, mean \pm SD of three experiments). In every case, the number of colonies formed in the absence of CTL was used to relativize the colony growth of treated cells. (B, D and F) IFN- $\gamma$ secretion by CTL was determined by ELISA as a measure of CTL activation. Mean \pm SEM of three experiments. ${ }^{*}$ p $<0.05$, ${ }^{* *}$ p $<0.01$, **** $\mathrm{p}<0.001$. CTL, cytotoxic T lymphocyte.

MEL-XY3 $3_{\text {SUR-PLX }}$ cells presented MDA mRNA levels similar to or even higher than those of parental cells (Fig. 7B). Most importantly, MART-1 and gp100 protein levels were similar in MEL-XY3 $3_{\text {SUR-PLX }}$ and MEL-XY $3_{\text {SUR-GDC }}$ compared to those of parental MEL-XY3 cells (Fig. 7B), thereby revealing persistent MDA synthesis. MITF mRNA expression was also analyzed in MEL-XY3 $3_{\text {SUR-PLX }}$ cells but no significant changes in expression were found (Fig. 7B).

It was therefore important to determine whether, although resistant to chemotherapy, MEL-XY3 $3_{\text {SUR }}$ cells could be killed by immunological effectors. First, we established that MEL-XY3 $3_{\text {SUR }}$ cells expressed, although at lower levels than the parental line, the HLA-A*0201 haplotype, in which MART-1 and gp100 peptides are presented (Fig. 7C). We then studied the susceptibility of MEL-XY3 $3_{\text {SUR }}$ cells to two CTL clones, HLA-A*0201-restricted and specific for gp100
(G154) and MART-1 (M26) antigens (29). We had previously shown that MEL-XY3 cells are lysed by specific CTL (36). We now demonstrated that MEL-XY3 $3_{\text {SUR-PLX }}$ cells were killed by specific CTL clones, as determined by clonogenic assays. At a 1:1 effector:target ratio, a 50\% lytic effect was observed, as evidenced by the reduction of colony formation; at higher ratios almost no cells survived. MEL-XY $3_{\text {SUR-GDC }}$ cells were also sensitive to CTL killing, although it is worth noting that MEL-XY3 $3_{\text {SUR-GDC }}$ cells were less clonogenic than MEL-XY3 $3_{\text {SUR-PLX }}$ cells (Fig. 8A). As a surrogate measure confirming that MEL-XY3 $3_{\text {SUR }}$ cells were sensitive to CTL action, IFN- $\gamma$ release after co-incubation of MEL-XY $3_{\text {SUR }}$ cells with CTL clones was assessed. A strong cytokine release was triggered by MEL-XY $3_{\text {SUR-PLX }}$, indicating a potent interaction between CTL and tumor cells, even stronger than with parental cells. However, almost no CTL activation 
occurred after incubation with MEL-XY3 $3_{\text {SUR-GDC }}$ cells, even though a lytic effect was observed (Fig. 8B). Similar results were obtained with the CTL clone specific for MART-1 (M26) (Fig. 8C and D). Equivalent results were obtained with the CTL clone specific for gp100 in MEL-XY13 and MEL-XY13 ${ }_{\text {SUR-PLX }}$ cells (Fig. 8E and F).

\section{Discussion}

CM patients harboring BRAF V600E mutations and treated with MAPKi almost invariably present with recurrence, as CM cells acquire different resistance mechanisms, most of them involving reactivation of the MAP kinase pathway (9-14), or activation of other proliferative pathways such as PI3K signaling $(37,38)$. Through the study of two CM cell lines, carrying BRAF V600E mutations, we provide evidence of an alternative resistance mechanism: prolonged treatment of BRAF-V600E CM cells with MAPKi induced surviving cell subpopulations, here named SUR, whose main characteristics were as follows. i) They are quiescent; ii) when the drugs are withdrawn SUR cells return to proliferation, albeit remaining equally sensitive to the drugs as the parental line; iii) they display a phenotype sharing features of CSC and senescent cells; and iv) they are sensitive to specific CD8 lymphocytes. In reference to quiescence, it was found that the inhibition attained with GDC-0973 was more profound than that attained with PLX4032. The time required to recover DNA synthesis after drug removal was dramatically different when cells were treated with PLX4032, GDC-0973 or their combination: a couple of days after PLX4032 removal, two weeks after GDC-0973 removal, and more than three weeks after PLX4032 and GDC-0973 combination-treatment removal, respectively. Coincidently, the clonogenicity of the SUR-GDC cells was 7-fold less than that of the SUR-PLX cells, which also pointed to a diminished vitality. In addition, the p-ERK levels observed in the MEL-XY3 ${ }_{\text {SUR-GDC }}$ cells were lower than these level in the MEL-XY3 $3_{\text {SUR-PLX }}$ cells. With respect to the phenotype of SUR cells, a mixture of protein expression normally attributed to CSC markers and senescence was observed. With respect to CSC markers, CD271 was greatly increased in the MEL-XY3 $3_{\text {SUR-PLX }}$ and MEL-XY3 $3_{\text {SUR-GDC }}$ cells. Redmer et al previously proposed that CD271 expression was essential for the tumorigenicity of CM cells (39). However, Cheli et al described CD271 as an imperfect CSC marker since only the slow growing cells among the $\mathrm{CD} 271^{+}$subpopulation presented increased tumorigenic potential (40). Our results support those of Ravindran Menon et al (41), who demonstrated that PLX4032 increased CD271 expression in CM cells and induced the transition into a slow cycling state. The same phenotype was also observed when cells were exposed to different types of stress, such as hypoxia or nutrient starvation, and the authors proposed that these changes were part of an early innate response program. In regard to the efflux pump ABCB5, MEL-XY3 expression increased within one week after exposure to PLX4032 and two weeks before CD271 started to increase. We suggest that an ABCB5 increase would allow some tumor cells to transitorily resist PLX4032 and GDC-0973 treatment, thereby allowing time to develop more stable survival mechanisms. Our results confirm that ABCB5-expressing cells pre-exist in melanoma as previously demonstrated $(31,42)$, and that such expression may be increased manifold in the SUR population after MAPK inhibition. In addition, Chartrain et al previously showed that treatment with PLX4032 leads to the selection of ABCB5-positive cells (43). The observed downregulation of CD133 (prominin-1) in SUR cells suggests that, in our conditions, this cell surface glycoprotein, expressed in CSC of different tumors (44-46), is not essential to maintain SUR conditions. Similar results were observed by Quintana et al who did not find any correlation between the expression of CD133 and ABCB5 with cell tumorigenicity (47).

MEL-XY3 $3_{\text {SUR-PLX }}$ also presented senescence-associated features, such as enhancement of SA- $\beta$-gal activity and a 10-fold increase in SOD2 (mitochondrial Mn-SOD2). Although some authors reported a diminution of SOD2 in senescent cells (48), it was shown that senescent drug-tolerant cells maintain low levels of reactive oxygen species and present enhanced expression levels of antioxidant enzymes (49). Moreover, the acquisition of a senescent phenotype has been proposed as an intermediate state that would allow escape from chemotherapeutic-induced death and would lead to a CSC-like phenotype (49). In an RPPA analysis comparing SUR-PLX cells with the parental line, important decreases in hyper-phosphorylated Rb, CDK1 and cyclin B1 were observed, demonstrating that PLX4032 induces a blockage of cell cycle and mitotic entry. The full reversibility of this blockage is supported by: i) regrowth of cells after drug removal, both with and without anchorage; and ii) the ability to generate tumors in immunodeficient mice. A recent study also reported that oncogene-induced senescence may not be irreversible and that the senescent state could give rise to tumor-initiating cells (50).

Most importantly, we also established that SUR cells are not below the radar of the immune system. Different studies suggested that PLX4032 induces MDA expression, although diminished MDA levels have also been reported after acquired resistance $(15,22)$. SUR cells express HLA-I molecules, MDAs, and are susceptible to CTL killing, suggesting that the combination of MAPKi with immunotherapy could eliminate cells that present this type of variable resistance. This would be especially important in patients who, after treatment with MAPKi, attain complete or nearly complete responses; after that moment treatment with anti-checkpoint inhibitors could trigger an attack of tumor SUR cells when the tumor mass is at its lowest and before resistance emerges.

In conclusion, we describe in this study the acquisition of a variable, drug-tolerant, immunosensitive phenotype, which would allow residual tumor cells to survive in the presence of inhibitors of the MAPK pathway, but remain sensitive to immune effectors. Further investigation will be required to establish the in vivo presence and relevance of this phenotype and its implication for targeted therapies.

\section{Acknowledgements}

This study was supported by the Agencia Nacional de Promoción Científica y Tecnológica (ANPCyT), the Fundación Cáncer, and the Fundación Sales and Fundación María Calderón de la Barca, Argentina. J.M. is a member of the National Research Council of Argentina (CONICET), and 
F.-P.M.R. and A.B. are fellows of the same institution. The funders had no role in the manuscript design, data collection and analysis, decision to publish, or preparation of the manuscript. J.M. received a research grant from ROCHE.

\section{References}

1. Davies H, Bignell GR, Cox C, Stephens P, Edkins S, Clegg S Teague J, Woffendin $\mathrm{H}$, Garnett MJ, Bottomley W, et al: Mutations of the BRAF gene in human cancer. Nature 417: 949-954, 2002.

2. Bollag G, Hirth P, Tsai J, Zhang J, Ibrahim PN, Cho H, Spevak W, Zhang C, Zhang Y, Habets G, et al: Clinical efficacy of a RAF inhibitor needs broad target blockade in $B R A F$-mutant melanoma. Nature 467: 596-599, 2010.

3. Chapman PB, Hauschild A, Robert C, Haanen JB, Ascierto P, Larkin J, Dummer R, Garbe C, Testori A, Maio M, et al; BRIM-3 Study Group: Improved survival with vemurafenib in melanoma with BRAF V600E mutation. N Engl J Med 364: 2507-2516, 2011.

4. Hauschild A, Grob JJ, Demidov LV, Jouary T, Gutzmer R, Millward M, Rutkowski P, Blank CU, Miller WH Jr, Kaempgen E, et al: Dabrafenib in $B R A F$-mutated metastatic melanoma: A multicentre, open-label, phase 3 randomised controlled trial. Lancet 380: 358-365, 2012.

5. King AJ, Arnone MR, Bleam MR, Moss KG, Yang J, Fedorowicz KE, Smitheman KN, Erhardt JA, Hughes-Earle A, Kane-Carson LS, et al: Dabrafenib; preclinical characterization, increased efficacy when combined with trametinib, while BRAF/MEK tool combination reduced skin lesions. PLoS One 8: e67583, 2013.

6. Hoeflich KP, Merchant M, Orr C, Chan J, Den Otter D, Berry L, Kasman I, Koeppen H, Rice K, Yang NY, et al: Intermittent administration of MEK inhibitor GDC-0973 plus PI3K inhibitor GDC-0941 triggers robust apoptosis and tumor growth inhibition. Cancer Res 72: 210-219, 2012.

7. Larkin J, Ascierto PA, Dréno B, Atkinson V, Liszkay G, Maio M, Mandalà M, Demidov L, Stroyakovskiy D, Thomas L, et al: Combined vemurafenib and cobimetinib in $B R A F$-mutated melanoma. N Engl J Med 371: 1867-1876, 2014.

8. Long GV, Stroyakovskiy D, Gogas H, Levchenko E, de Braud F, Larkin J, Garbe C, Jouary T, Hauschild A, Grob JJ, et al: Combined BRAF and MEK inhibition versus BRAF inhibition alone in melanoma. N Engl J Med 371: 1877-1888, 2014.

9. Nazarian R, Shi H, Wang Q, Kong X, Koya RC, Lee H, Chen Z, Lee MK, Attar N, Sazegar H, et al: Melanomas acquire resistance to B-RAF(V600E) inhibition by RTK or N-RAS upregulation. Nature 468: 973-977, 2010.

10. Villanueva J, Vultur A, Lee JT, Somasundaram R, FukunagaKalabis M, Cipolla AK, Wubbenhorst B, Xu X, Gimotty PA, Kee D, et al: Acquired resistance to BRAF inhibitors mediated by a RAF kinase switch in melanoma can be overcome by cotargeting MEK and IGF-1R/PI3K. Cancer Cell 18: 683-695, 2010.

11. Shi H, Moriceau G, Kong X, Lee MK, Lee H, Koya RC, Ng C, Chodon T, Scolyer RA, Dahlman KB, et al: Melanoma wholeexome sequencing identifies ${ }^{\mathrm{V} 600 \mathrm{E}} B-R A F$ amplification-mediated acquired B-RAF inhibitor resistance. Nat Commun 3: 724, 2012.

12. Johannessen CM, Boehm JS, Kim SY, Thomas SR, Wardwell L, Johnson LA, Emery CM, Stransky N, Cogdill AP, Barretina J, et al: COT drives resistance to RAF inhibition through MAP kinase pathway reactivation. Nature 468: 968-972, 2010.

13. Straussman R, Morikawa T, Shee K, Barzily-Rokni M, Qian ZR, Du J, Davis A, Mongare MM, Gould J, Frederick DT, et al: Tumour micro-environment elicits innate resistance to RAF inhibitors through HGF secretion. Nature 487: 500-504, 2012.

14. Poulikakos PI, Persaud Y, Janakiraman M, Kong X, Ng C, Moriceau G, Shi H, Atefi M, Titz B, Gabay MT, et al: RAF inhibitor resistance is mediated by dimerization of aberrantly spliced BRAF(V600E). Nature 480: 387-390, 2011.

15. Long GV, Wilmott JS, Haydu LE, Tembe V, Sharma R, Rizos H, Thompson JF, Howle J, Scolyer RA and Kefford RF: Effects of BRAF inhibitors on human melanoma tissue before treatment, early during treatment, and on progression. Pigment Cell Melanoma Res 26: 499-508, 2013.

16. Bivona TG and Doebele RC: A framework for understanding and targeting residual disease in oncogene-driven solid cancers. Nat Med 22: 472-478, 2016.
17. Sharma SV, Lee DY, Li B, Quinlan MP, Takahashi F, Maheswaran S, McDermott U, Azizian N, Zou L, Fischbach MA, et al: A chromatin-mediated reversible drug-tolerant state in cancer cell subpopulations. Cell 141: 69-80, 2010.

18. Hodi FS, O'Day SJ, McDermott DF, Weber RW, Sosman JA, Haanen JB, Gonzalez R, Robert C, Schadendorf D, Hassel JC, et al: Improved survival with ipilimumab in patients with metastatic melanoma. N Engl J Med 363: 711-723, 2010.

19. Robert C, Long GV, Brady B, Dutriaux C, Maio M, Mortier L, Hassel JC, Rutkowski P, McNeil C, Kalinka-Warzocha E, et al: Nivolumab in previously untreated melanoma without $B R A F$ mutation. N Engl J Med 372: 320-330, 2015.

20. Robert C, Schachter J, Long GV, Arance A, Grob JJ, Mortier L, Daud A, Carlino MS, McNeil C, Lotem M, et al; KEYNOTE-006 investigators: Pembrolizumab versus Ipilimumab in advanced melanoma. N Engl J Med 372: 2521-2532, 2015.

21. Boni A, Cogdill AP, Dang P, Udayakumar D, Njauw CN, Sloss CM, Ferrone CR, Flaherty KT, Lawrence DP, Fisher DE, et al: Selective BRAF ${ }^{\mathrm{V} 600 \mathrm{E}}$ inhibition enhances T-cell recognition of melanoma without affecting lymphocyte function. Cancer Res 70: 5213-5219, 2010.

22. Frederick DT, Piris A, Cogdill AP, Cooper ZA, Lezcano C, Ferrone CR, Mitra D, Boni A, Newton LP, Liu C, et al: BRAF inhibition is associated with enhanced melanoma antigen expression and a more favorable tumor microenvironment in patients with metastatic melanoma. Clin Cancer Res 19: 1225-1231, 2013.

23. Wilmott JS, Long GV, Howle JR, Haydu LE, Sharma RN, Thompson JF, Kefford RF, Hersey P and Scolyer RA: Selective BRAF inhibitors induce marked T-cell infiltration into human metastatic melanoma. Clin Cancer Res 18: 1386-1394, 2012.

24. von Euw EM, Barrio MM, Furman D, Bianchini M, Levy EM, Yee C, Li Y, Wainstok R and Mordoh J: Monocyte-derived dendritic cells loaded with a mixture of apoptotic/necrotic melanoma cells efficiently cross-present gp100 and MART-1 antigens to specific CD8 ${ }^{+} \mathrm{T}$ lymphocytes. J Transl Med 5: 19, 2007.

25. Barrio MM, de Motta PT, Kaplan J, von Euw EM, Bravo AI, Chacón RD and Mordoh J: A phase I study of an allogeneic cell vaccine (VACCIMEL) with GM-CSF in melanoma patients. J Immunother 29: 444-454, 2006.

26. Livak KJ and Schmittgen TD: Analysis of relative gene expression data using real-time quantitative PCR and the $2^{-\Delta \Delta C T}$ method. Methods 25: 402-408, 2001.

27. Barrio MM, Abes R, Colombo M, Pizzurro G, Boix C, Roberti MP, Gélizé E, Rodriguez-Zubieta M, Mordoh J and Teillaud JL: Human macrophages and dendritic cells can equally present MART-1 antigen to $\mathrm{CD}^{+} \mathrm{T}$ cells after phagocytosis of gamma-irradiated melanoma cells. PLoS One 7: e40311, 2012.

28. Debacq-Chainiaux F, Erusalimsky JD, Campisi J and Toussaint O: Protocols to detect senescence-associated beta-galactosidase (SA- $\beta$ gal) activity, a biomarker of senescent cells in culture and in vivo. Nat Protoc 4: 1798-1806, 2009.

29. Yee C, Thompson JA, Byrd D, Riddell SR, Roche P, Celis E and Greenberg PD: Adoptive T cell therapy using antigen-specific $\mathrm{CD}^{+} \mathrm{T}$ cell clones for the treatment of patients with metastatic melanoma: In vivo persistence, migration, and antitumor effect of transferred T cells. Proc Natl Acad Sci USA 99: 16168-16173, 2002.

30. Boiko AD, Razorenova OV, van de Rijn M, Swetter SM, Johnson DL, Ly DP, Butler PD, Yang GP, Joshua B, Kaplan MJ, et al: Human melanoma-initiating cells express neural crest nerve growth factor receptor CD271. Nature 466: 133-137, 2010.

31. Schatton T, Murphy GF, Frank NY, Yamaura K, WaagaGasser AM, Gasser M, Zhan Q, Jordan S, Duncan LM, Weishaupt C, et al: Identification of cells initiating human melanomas. Nature 451: 345-349, 2008.

32. Frank NY,Margaryan A,Huang Y,Schatton T, Waaga-Gasser AM, Gasser M, Sayegh MH, Sadee W and Frank MH: ABCB5mediated doxorubicin transport and chemoresistance in human malignant melanoma. Cancer Res 65: 4320-4333, 2005.

33. Haferkamp S, Borst A, Adam C, Becker TM, Motschenbacher S, Windhövel S, Hufnagel AL, Houben R and Meierjohann S: Vemurafenib induces senescence features in melanoma cells. J Invest Dermatol 133: 1601-1609, 2013.

34. Li Z, Jiang K, Zhu X, Lin G, Song F, Zhao Y, Piao Y, Liu J, Cheng W, Bi X, et al: Encorafenib (LGX818), a potent BRAF inhibitor, induces senescence accompanied by autophagy in BRAFV600E melanoma cells. Cancer Lett 370: 332-344, 2016. 
35. Michaloglou C, Vredeveld LC, Soengas MS, Denoyelle C, Kuilman T, van der Horst CM, Majoor DM, Shay JW, Mooi WJ and Peeper DS: BRAF ${ }^{\mathrm{E} 600}$-associated senescence-like cell cycle arrest of human naevi. Nature 436: 720-724, 2005

36. Aris M, Zubieta MR, Colombo M, Arriaga JM, Bianchini M, Alperovich M, Bravo AI, Barrio MM and Mordoh J: MART-1and gp100-expressing and -non-expressing melanoma cells are equally proliferative in tumors and clonogenic in vitro. J Invest Dermatol 132: 365-374, 2012.

37. Samatar AA and Poulikakos PI: Targeting RAS-ERK signalling in cancer: Promises and challenges. Nat Rev Drug Discov 13: 928-942, 2014.

38. Holderfield M, Deuker MM, McCormick F and McMahon M: Targeting RAF kinases for cancer therapy: BRAF-mutated melanoma and beyond. Nat Rev Cancer 14: 455-467, 2014.

39. Redmer T, Welte Y, Behrens D, Fichtner I, Przybilla D, Wruck W, Yaspo ML, Lehrach H, Schäfer R and Regenbrecht CR: The nerve growth factor receptor CD271 is crucial to maintain tumorigenicity and stem-like properties of melanoma cells. PLoS One 9: e92596, 2014.

40. Cheli Y, Bonnazi VF, Jacquel A, Allegra M, De Donatis GM, Bahadoran P, Bertolotto C and Ballotti R: CD271 is an imperfect marker for melanoma initiating cells. Oncotarget 5: 5272-5283, 2014.

41. Ravindran Menon D, Das S, Krepler C, Vultur A, Rinner B, Schauer S, Kashofer K, Wagner K, Zhang G, Bonyadi Rad E, et al: A stress-induced early innate response causes multidrug tolerance in melanoma. Oncogene 34: 4448-4459, 2015.

42. Sharma BK, Manglik V, O'Connell M, Weeraratna A, McCarron EC, Broussard JN, Divito KA, SimbulanRosenthal CM, Rosenthal DS and Zapas JL: Clonal dominance of $\mathrm{CD} 133^{+}$subset population as risk factor in tumor progression and disease recurrence of human cutaneous melanoma. Int J Oncol 41: 1570-1576, 2012.
43. Chartrain M, Riond J, Stennevin A, Vandenberghe I, Gomes B, Lamant L, Meyer N, Gairin JE, Guilbaud N and Annereau JP: Melanoma chemotherapy leads to the selection of ABCB5-expressing cells. PLoS One 7: e36762, 2012.

44. Singh SK, Hawkins C, Clarke ID, Squire JA, Bayani J, Hide T, Henkelman RM, Cusimano MD and Dirks PB: Identification of human brain tumour initiating cells. Nature 432: 396-401, 2004.

45. Singh SK, Clarke ID, Terasaki M, Bonn VE, Hawkins C, Squire J and Dirks PB: Identification of a cancer stem cell in human brain tumors. Cancer Res 63: 5821-5828, 2003.

46. Ren F, Sheng WQ and Du X: CD133: A cancer stem cells marker, is used in colorectal cancers. World J Gastroenterol 19: 2603-2611, 2013.

47. Quintana E, Shackleton M, Sabel MS, Fullen DR, Johnson TM and Morrison SJ: Efficient tumour formation by single human melanoma cells. Nature 456: 593-598, 2008.

48. Velarde MC, Flynn JM, Day NU, Melov S and Campisi J: Mitochondrial oxidative stress caused by Sod2 deficiency promotes cellular senescence and aging phenotypes in the skin. Aging (Albany NY) 4: 3-12, 2012.

49. Achuthan S, Santhoshkumar TR, Prabhakar J, Nair SA and Pillai MR: Drug-induced senescence generates chemoresistant stemlike cells with low reactive oxygen species. J Biol Chem 286: 37813-37829, 2011

50. Leikam C, Hufnagel AL, Otto C, Murphy DJ, Mühling B, Kneitz S, Nanda I, Schmid M, Wagner TU, Haferkamp S, et al: In vitro evidence for senescent multinucleated melanocytes as a source for tumor-initiating cells. Cell Death Dis 6: e1711, 2015. 